\title{
FIRST RECORD OF THE LARGE-HEADED GOBY, MILLERIGOBIUS MACROCEPHALUS (ACTINOPTERYGII: PERCIFORMES: GOBIIDAE), FROM ITALY
}

\author{
Salvatore GIACOBBE ${ }^{1 *}$, Andrea SPINELLI ${ }^{1}$, Sergio DE MATTEO ${ }^{2}$, and Marcelo KOVAČIĆ ${ }^{3}$ \\ ${ }^{1}$ University of Messina, Department of Chemical, Biological, Pharmaceutical and Environmental Sciences, Messina, Italy \\ ${ }^{2}$ Mare Nostrum Italia, Messina, Italy \\ ${ }^{3}$ Natural History Museum Rijeka, Rijeka, Croatia
}

\begin{abstract}
Giacobbe S., Spinelli A., De Matteo S., Kovačić M. 2016. First record of the large-headed goby, Millerigobius macrocephalus (Actinopterygii: Perciformes: Gobiidae), from Italy. Acta Ichthyol. Piscat. 46 (1): 49-52.
\end{abstract}

\begin{abstract}
Two confined populations of an inadequately known gobiid, Millerigobius macrocephalus (Kolombatović, 1891), new species for Italy, have been reported for the protected areas of "Capo Peloro Lagoon" and "Marinello Lakes", NE Sicily. The specimens found were described and illustrated. Additional data were provided on the habitat preferences of this fish species. The authors emphasize the need for biodiversity inventories of inadequately studied Mediterranean lagoons.
\end{abstract}

Keywords: Mediterranean, lagoon, conservation, inventory, transitional waters

Millerigobius macrocephalus (Kolombatović, 1891) is a Mediterranean endemic species that has mostly been recorded in the eastern basins (Adriatic, Aegean, and Levantine) (Bath 1973, Miller 1977, Bogorodsky et al. 2010), and less frequently in the central-occidental areas (Ramos-Esplà and Perèz Ruzafa 1987, Bouchereau and Tomasini 1989, Bouchereau 2002, Kovačić et al. 2013). Its introduction to the Black Sea has recently been documented (Boltačëv et al. 2010). In this paper, we report first Italian records of this scarcely known gobiid. We found the fish specimens in two protected areas "Marinello Lakes" and "Capo Peloro Lagoon" (Fig. 1). The presently reported findings of $M$. macrocephalus in the above-mentioned Mediterranean lagoons also expand our knowledge on morphology and habitat preferences of this poorly known species (Abdul Malak et al. 2011).

The Natural Reserve "Marinello Lakes", (ITA 030012), located on the Tyrrhenian coasts of Sicily, represents one of the last examples of brackish coastal environments, in the north-eastern Sicily, which are relatively undisturbed by human activity. This reserve consists of a series of small basins, which are characterised by relatively high depths (3-6 m), as for this kind of habitat. In the last two decades, a trend of increasing mollusc diversity associated with increasing mud depositions was observed (Leonardi and Giacobbe 2001).
The "Capo Peloro Lagoon", separating the Ionian from the Tyrrhenian Sea, is a zone of special protection and a site of community interest (ITA 030008). The lagoon, is formed by two connected basins, Ganzirri and Faro, both subjected to high anthropogenic pressure. Unfortunately no faunistic or floristic inventory has recently been made of this ecosystem. The ichthyofauna of Capo Peloro Lagoon is known only from an outdated report of

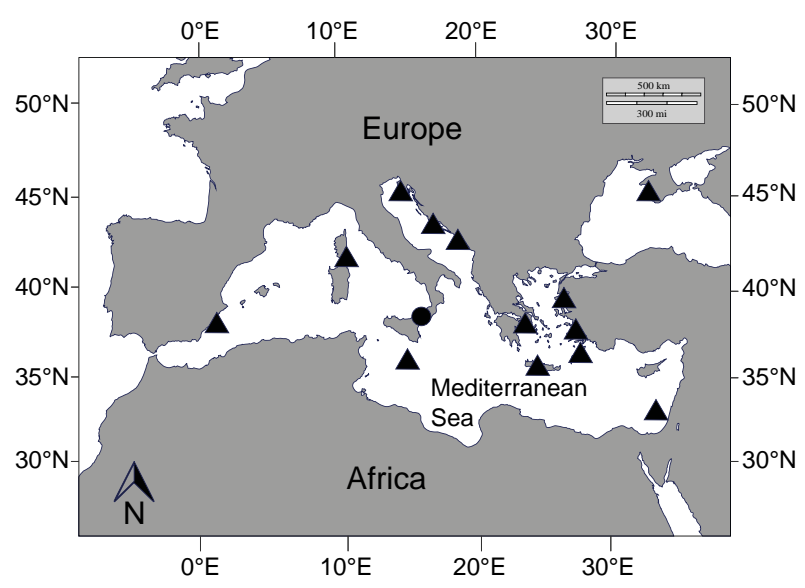

Fig. 1. Distribution of Millerigobius macrocephalus; Triangles indicate previous records, circle indicates presently reported records in NE Sicily

\footnotetext{
* Correspondence: Dr. Salvatore Giacobbe, Dipartimento di Scienze chimiche, biologiche, farmaceutiche e ambientali, Università degli Studi di Messina, Via F. Stagno D’Alcontres 31, 98166 Messina, Italy, phone: +090 6765540, fax: +090 393 409, e-mail: (SG) sgiacobbe@unime.it, (AS) andreaspinelli1990@gmail.com, (SDM) sergio.dematteo@hotmail.it, (MK) marcelo@prirodoslovni.com.
} 
Cavaliere (1967), whilst the fish fauna of Marinello Lakes has never been inventoried.

In the frames of the presently report study the macrobenthic fauna of the Faro Lake has been investigated monthly since 2010 in the framework of the program of the Provincia Regionale di Messina, entitled "Settlement dynamics and colonization of allochthonous assemblages in the Capo Peloro Lagoon". Comparative surveys were also conducted, by the present authors, in the Marinello Lakes since November 2013, which were explored from the shore, by snorkelling, and by SCUBA diving towards the centre of the basins, 3-6 m depth. In the same period, a study intended to detect possible presence of gobiid fishes was also carried out in the Capo Peloro Lagoon. The observed specimens were photographed in situ, geographic coordinates were recorded, and environmental conditions were described as much as possible. Only as small number of specimens was collected from each area, to limit the impact on those confined populations. The specimens were captured by hand net $(30 \mathrm{~cm}$ mouth opening, $0.5 \mathrm{~mm}$ mesh size), photographed to describe the live coloration, and preserved in $4 \%$ formaldehyde (3 specimens) and in 95\% ethanol (4 specimens). Species determination was carried out at the Natural History Museum Rijeka, on five specimens (PMR), and their morphological characters were compared with other two specimens examined at DiSBA, Messina University (DISBA-EB). Two additional specimens were maintained in aquaria for in vivo observations. The diagnosis is a minimum combination of characters that positively identify the collected specimens among species of the family Gobiidae in the CLOFNAM area (Miller 1986, Ahnelt and Dorda 2004, references therein). The meristic methods used followed Schliewen and Kovačić (2008). The terminology of the lateral-line system followed Sanzo (1911) and Miller (1986).

Family GOBIIDAE

Genus Millerigobius Bath, 1973

Millerigobius macrocephalus (Kolombatović, 1891)

Material examined: male, $34.5+8.0$ (standard length + caudal fin length) mm (PMR VP3354), female, $24.6+$ $5.9 \mathrm{~mm}$ (PMR VP3355), female, $26.8+6.1 \mathrm{~mm}$ (PMR VP3356), male, $38.0+7.0 \mathrm{~mm}$ (DISBA-EB-0864), all from Mergolo Lake, Marinello Lakes, Messina, 15 January 2014, collector A. Spinelli. Male, 29.0+7.2 mm (PMR VP3357), male, $34.6+8.3 \mathrm{~mm}$ (PMR VP3358), male, $28.0+5.0 \mathrm{~mm}$ (DISBA-EB-0865), all from Faro lake, Capo Peloro Lagoon, Messina, 17 January 2014, collector S. De Matteo.

Diagnosis: The following minimum combination of characters positively identify the researched specimen as Millerigobius macrocephalus among Mediterranean species of Gobiidae family: (1) suborbital papillae without longitudinal row a; (2) anterior oculoscapular and preopercular canals present, posterior oculoscapular canal absent; (3) pelvic fins united, forming complete disc; (4) interorbital papillae present.
Description: Body moderately elongate, laterally compressed at caudal peduncle, head large and moderately depressed. Anterior nostril tubular, long, reaching upper lip, without process from rim. Posterior nostril also erected. Eyes dorsolateral, eye contour usually going slightly above dorsal profile. Mouth oblique, posterior angle of jaws below pupil. Branchiostegal membrane attached to entire side of isthmus. Fins: first dorsal fin VI; second dorsal fin I/10-11 (10:2, 11:5); anal fin I/9; caudal fin 15-16 (15:5, 16:2) branched rays, 17 articulated rays; pectoral fin 15-16 (15:5, 16:2); pelvic fin I/5 + I/5. First dorsal fin rounded, of similar height as second dorsal fin. Three to four uppermost pectoral fin rays moderately free at tips. Pelvic fin complete and rounded, not reaching anus posteriorly; anterior transverse membrane of pelvic fin reduced (height in midline $1 / 4$ or less of length of pelvic spine), with straight edge and without lateral lobes. Caudal fin rounded. Body with ctenoid scales, scales in lateral series 29-31 (29:1, 30:1, 31:5), scales in transverse series 8-9 (8:2, 9:5). Head, predorsal area and breast naked. Belly covered with cycloid scales. Head with anterior oculoscapular and preopercular canals, with pores $\sigma, \lambda, \kappa, \omega, \alpha, \beta, \rho$, and $\gamma, \delta, \varepsilon$, respectively. Rows of sensory papillae: No suborbital row $a$. Seven transverse suborbital rows of sensory papillae. Five transverse suborbital rows before, two above, one below longitudinal row $b$. Transverse suborbital rows 2 and 3 more distant from orbit, other suborbital rows $(1,4,5,6,7)$ begin close to orbit. Row 5 continuous or divided in upper and lower parts. Row $b$ anteriorly beginning below rear border of eye at row 5 or near it, dividing row 6 in two parts. Suborbital row $d$ continuous. Predorsal area with transversal row $n$ behind pore $\omega$; transversal rows $o$ distant from fellow in dorsal midline (except in one specimen); row $g$ ends anteriorly in level of row o or slightly behind, posterior part of row $g$ above beginning of row $m$; longitudinal row $h$ of variable occurrence, continuous or divided in anterior and posterior parts. Transversal interorbital row $p$ as two sister rows present between pores $\lambda$ and $\kappa$. Live coloration: body and head brown, greyish brown to greyish green i.e., darkness variable among specimens; about six to eight vertical broad dark bands on body with narrow pale stripes between, present along lateral side below dorsal fins. Reticulate pattern, formed by dark markings along scale margins visible in less dark specimens. Head unequally pigmented with pale curved band going from pectoral fin base over upper opercle and passing dorsal midline immediately behind eye to another lateral side. Another, smaller pale stripe more or less visible on head between lower eye edge and posterior lips. Fin pigmented in larger and darker specimens, look mostly transparent in small brighter specimens. Coloration of preserved specimen variable: body more or less greyish brown, without any recognisable pattern in males, one female with white dots scattered over body and head and other female with still visible vertical stripes from live coloration. Reticulate pattern, formed by dark markings along scale margins present. Head pigmented, marbled.

In the "Marinello Lakes", a specimen of the largeheaded goby was observed solely in Mergolo Lake, for a total of almost 50 specimens, distributed along $200 \mathrm{~m}$ 
of shoreline, within the area covering ca. 0.3 ha, with the centre at $38^{\circ} 8^{\prime} 20^{\prime \prime} \mathrm{N}, 15^{\circ} 3^{\prime} 56^{\prime \prime} \mathrm{E}$. The habitat, ranging from a few $\mathrm{cm}$ to $1 \mathrm{~m}$ in depth, consisted of flat rocks emerging from compact silty sand sediments, locally covered by floating algal masses of Enteromorpha sp., where the specimens could hide when threatened (Fig. 2A).

In the "Capo Peloro Lagoon Reserve", about 20 specimens of Millerigobius macrocephalus were observed, exclusively in Faro Lake. The species occurred in a shallow area, covering about 1 ha, with the centre at $38^{\circ} 16^{\prime} 77^{\prime \prime} \mathrm{N}, 15^{\circ} 38^{\prime} 90^{\prime \prime} \mathrm{E}$. The lake floor, almost $1 \mathrm{~m}$ depth, was characterised by sand and shell debris (Fig. 2B) with patches of sea grass, Cymodocea nodosa, and sparse hard substrates associated with the oyster culture practices. The specimens of the large-headed goby settled both in natural and artificial substrates, although most often they occupied empty shells of Crassostrea gigas and Ostrea edulis. In the aquaria (Fig. 2C), acclimatisation was rapid, showing an active and complex homing behaviour.

The presently reported findings, not only enriched the checklist of the Italian fauna, but also expanded our knowledge about some natural reserves in terms of their biodiversity. They also constituted a symbolic step in studying data-deficient environments of southern Mediterranean lagoons.

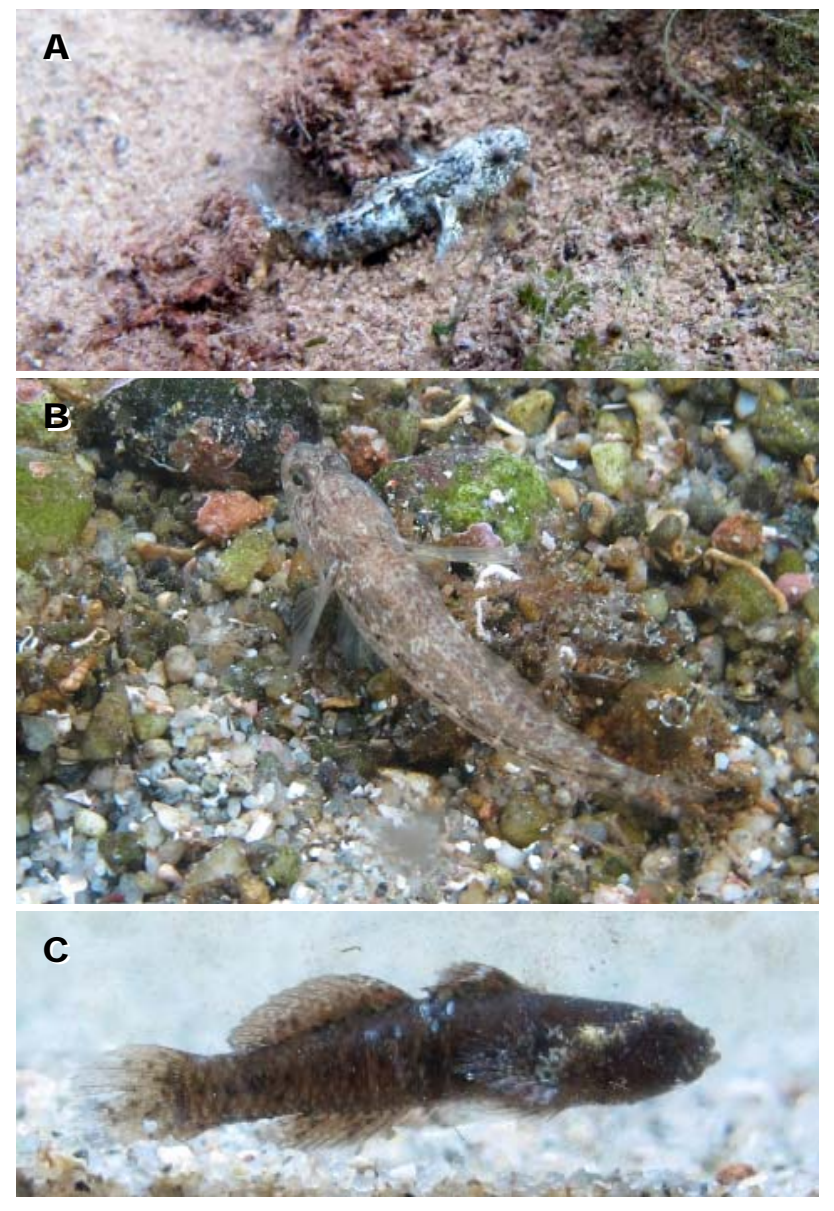

Fig. 2. Millerigobius macrocephalus: specimen from Mergolo Lake on rocky-floor (A); specimen from Faro Lake on sandy-gravel substrate (B); specimen from Mergolo Lake in aquarium $(\mathbf{C})$

\section{ACKNOWLEDGEMENTS}

This research has been sponsored by the Provincia Regionale di Messina, the official management body of the reserve. Facilities have been provided by the mussel farm FARAU s.r.l. A relevant field research contribution was also provided by the student Davide Romeo, which first spotted "a small goby fish" in Mergolo Lake.

\section{REFERENCES}

Abdul Malak D., Livingstone S.R., Pollard D., Polidoro B.A., Cuttelod A., Bariche M., Bilecenoglu M., Carpenter K.E., Collette B.B., Francour P., Goren M., Kara M.H., Massutí E., Papaconstantinou C., Tunesi L. 2011. Overview of the conservation status of the marine fishes of the Mediterranean Sea. International Union for Conservation of Nature and Natural Resources (IUCN), Gland, Switzerland and Malaga, Spain.

Ahnelt H., Dorda J. 2004. Gobioid fishes from the north eastern Atlantic and the Mediterranean: New records and rarely found species. Annalen des Naturhistorischen Museums in Wien 105B (1): 5-19.

Bath H. 1973. Wiederbeschreibung der Grundelart Gobius macrocephalus Kolombatović aus dem Mittelmeer und Aufstellung einer neuen Gattung Millerigobius (Teleostei: Gobioidea: Gobiinae). Senckenbergiana Biologica 54 (4-6): 303-310.

Bogorodsky S., Kovačić M., Ozen O., Bilecenoglu M. 2010. Records of two uncommon goby species (Millerigobius macrocephalus, Zebrus zebrus) from the Aegean Sea. Acta Adriatica 51 (2): 217-222.

BoltačëvA.R.[BoltachevA.R.],KarpovaE.P.,Mačkevskij V.K. [Machkevskiy V.K.] 2010. Naturalizaciâ byčka Millera Millerigobius macrocephalus (Perciformes, Gobiidae) v Sevastopol'skoj buhte Čërnogo morâ. ["The Naturalization of Miller's goby Millerigobius macrocephalus (Perciformes, Gobiidae) in the Sevastopol Bay of the Black Sea.'] Morskoj èkologičeskij žurnal 9 (1): 32. [In Russian.]

Bouchereau J.-L. 2002. First data on the demography and growth of Millerigobius macrocephalus (Kolombatović, 1891) (Teleostei; Gobiidae), in Corsica (France). Acta Adriatica 43 (1): 77-85.

Bouchereau J.-L., Tomasini J.A. 1989. Note sur la présence de Chromogobius zebratus (Kolombatovic, 1891) et de Millerigobius macrocephalus (Kolombatovic, 1891) (Teleostei, Percomorphi, Gobioidei, Gobiidae) sur les côtes de Corse, France. Bulletin de la Société Zoologique de France 114 (3): 105-110.

Cavaliere A. 1967. Fauna e flora dei laghi di Faro e Ganzirri (Messina); Nota $1^{\text {a }}$, i teleostei del lago di Faro. [Fauna and flora of the lakes Faro and Ganzirri (Messina); Note 1, teleosteans of lake Faro.] Bollettino di Pesca, Piscicoltura e Idrobiologia del lago di Faro 22 (1): 83-102. [In Italian.]

Kovačić M., Bonello J.J., Evans J. 2013. Three new records of Gobiidae from Malta with morphology, colouration and identification of the smallest known juveniles of two small gobiid species. Cybium 37 (4): 233-239. 
Leonardi M., Giacobbe S. 2001. [Chapter 39] The Oliveri-Tindari Lagoon (Messina, Italy): Evolution of the trophic-sedimentary environment and mollusc communities in the last twenty years. Pp. 305-310.

DOI: 10.1007/978-88-470-2105-1_39. In: Faranda F.M., Guglielmo L., Spezie G. (eds.) Mediterranean ecosystems: Structures and processes. Springer-Milan, Italy.

DOI: $10.1007 / 978-88-470-2105-1$

Miller P.J. 1977. Gobies from Rhodes and the systematic features of Zebrus zebrus (Teleostei: Gobiidae). Zoological Journal of the Linnean Society 60 (4): 339-362.

DOI: 10.1111/j.1096-3642.1977.tb00839.x

Miller P.J. 1986. Gobiidae. Pp. 1019-1085. In: Whitehead P.J.P., Bauchot M.-L., Hureau J.-C., Nielsen J., Tortonese E. (eds.) Fishes of the North-eastern Atlantic and the Mediterranean. Vol. 3. UNESCO, Paris.
Ramos-Esplà A.A., Pérez-Ruzafa A. 1987. Presencia de Millerigobius macrocephalus (Kolombatović, 1891) (Teleostei: Gobiidae) en el Mediterraneo occidental, con notas sobre su biologia. Anales de Biologìa 11 (3): 31-35.

Sanzo L. 1911. Distribuzione delle papille cutanee (organi ciatiformi) e suo valore sistematico nei Gobi. [Distribution of the cutineous papillae (cup-shaped organ) and its value in the systematics of gobies.] Mittheilungen aus der zoologischen Station zu Neapel 20 (2): 249-328. [In Italian.]

Schliewen U.K., Kovačić M. 2008. Didogobius amicuscaridis spec. nov. and D. wirtzi spec. nov., two new species of symbiotic gobiid fish from São Tomé and Cape Verde islands (Perciformes, Gobidae). Spixiana 31 (2): 247-261.

Received: 12 August 2015

Accepted: 3 March 2016

Published electronically: 31 March 2016 